\title{
Laadun tekijät: yliopistollisen täydennyskoulutuksen itsearviointi
}

\author{
Kauko Hämäläinen 1993. \\ Yliopistollisen \\ täydennyskoulutuksen arviointi. \\ Helsingin yliopiston Vantaan \\ täydennyskoulutuslaitoksen \\ julkaisuja 8:1993. Yliopistopaino.
}

$\mathbf{Y}$ liopistollisen täydennyskoulutuksen veteraaneihin kuuluva Kauko Hämäläinen tarkastelee yliopistojen täydennyskoulutusta, sen laatua ja arviointitapoja vastikään julkaistussa raportissaan. Kyseessä on opetusministeriön rahoittaman tutkimusprojektin ensimmäinen osa, eräänlainen taustaraportti.

Raportissa kuvataan yliopistojen täydennyskoulutusta yleensä, koulutuksen tuloksellisuutta ja laadun käsitteitä sekä esitetään esimerkkejä yliopistojen täydennyskoulutuksen arvioinnista. Tarkastelua pyritään syventämään lähinnä opetusalaa koskevin esimerkein.

Raportti on tiivis katsaus yliopistojen täydennyskoulutuksen arvioinnin lähtökohtiin. Kuten hyvän taustaraportin kuuluukin tehdä, se herättää odotuksia siitä, että jatko-osissa päästään konkreettisempiin tuloksiin. Samalla raportti virittää sellaisenaankin kysymyksiä ja kommentteja, joita seuraavassa esitän. Se minulle sallittanee, kun olen - ainakin väliaikaisesti - "katsomon puolella".

$\mathbf{R}$ aportissa määritellään yliopistollinen täydennyskoulutus yliopistojen järjestämäksi koulutukseksi, joka on suunniteltu lähinnä korkeakoulututkinnon suorittaneille ja ammatissa toimiville. Sen toteuttamisesta huolehtivat etu- päässä jokaisessa yliopistossa erillislaitoksina toimivat täydennyskoulutuslaitokset.

Koulutuksen laatu-käsite määritellään taas todetuksi yhdenmukaisuudeksi eri sidosryhmien vaatimusten kanssa. Sidosryhmiä täydennyskoulutuslaitosten kannalta ovat $\mathrm{mm}$. koulutettavat ja heidän työnantajansa, yliopistojen tutkijat ja opettajat sekä valtionhallinnon virkamiehet.

Nämä kaksi lähtökohtaa johtavat siihen, että raportti painottuu kuin huomaamattaan yliopistojen täydennyskoulutuskeskusten toiminnan tai laadun arviointiin. Itse täydennyskoulutus ja sen organisointitapa sekoittuvat.

Tämä saattaa tuntua saivartelulta niiden näkökulmasta, jotka tekevät täydennyskoulutuskeskuksissa arvokasta työtä aikuiskoulutuksen kehittämiseksi. Sidosryhmätarkastelu on näyttänyt kuitenkin osoittavan niin Helsingin kuin Turun yliopistoissa, että yliopistojen opettajat ja tutkijat eivät täysin miellä täydennyskoulutuskeskusten toimintatapaa.

Minusta on selvää, että yliopistojen opettajilta ja tutkijoilta ei pitkälläkään aikavälillä tule oikeutusta sen enempää täydennyskoulutukselle kuin täydennyskoulutuskeskuksille. Täydennyskoulutus on yliopistojen sivutuote ja päätetuotteina tulevat ilman muuta pysymään tutkimus, tieteellinen jatkokoulutus ja nuorten yliopistollinen peruskoulutus.

Tunnustusta ja oikeutusta voisikin hakea koulutettavilta ja työnantajilta. Jos he pitävät saamaansa koulutusta hyvänä ja (pitemmällä ajalla) vaikuttavana, on koulutus laadukasta. Tällaisia 
selvityksiä tehtäneen täydennyskoulutuskeskuksissa aika ajoin, mutta kattavaa yhteenvetoa ei tuloksista liene olemassa.

Raportissa esitetään kiinnostava esimerkki USA:n yliopistojen täydennyskoulutuskeskusten yhdistyksen laatimasta ohjeistosta. Siinä kuvataan 13-kohtaisesti täydennyskoulutuksen laatuvaatimuksia ( $\mathrm{mm}$. koulutuksen taso, valintakriteerit, suunnittelu, toteutus jne.) Jään pohtimaan, voisiko meillä vaikkapa täydennyskoulutuskeskusten johtajien neuvosto saada aikaan samanlaisen epävirallisen suosituksen. Se voisi edesauttaa täydennyskoulutuksen legitimaatiota yhtä lailla kuin erilaiset PD-tutkinnotkin.

os pidetään annettuna sitä, että yliopistojen täydennyskoulutuksen suomalaisessa mallissa sen toteuttajina ja välittäjinä ovat täydennyskoulutuslaitokset, voitaisiin paneutua tuon välitystehtävän ytimeen, suunnittelijoihin (koulutussuunnittelijoihin, koulutuspäälliköihin jne.): millaisena he kokevat tehtävänsä. Ovatko he verrattavissa korkeatasoisiin toimittajiin, jotka liittävät yhteen tieteellistä ja käytännöllistä tietoa? Pitääkö vertauskohta hakea yliopistomaailman tutkijoista? Vai onko kyseessä vain enemmän tai vähemmän tekninen välitystehtävä? Tässä taitaisi olla itsereflektion paikka.
Täydennyskoulutus on varsin uusi toimintamuoto Suomen yliopistoissa. Monet sen veteraaneista ovat edelleen aktiivisesti mukana kentällä. Silti olisi jo aika ryhtyä dokumentoimaan, kuinka kaikki oikein alkoi ja mitä silloin ennen mahdollisesti ajateltiin. Opetusministeriöltä ei olisi huono sijoitus panna joku kirjaamaan vaikkapa Pentti Salmelinin, Heikki Lammen, Vilho Hirven, Esko Vesikansan ja monen muun vaikuttajan ajatuksia.

Kauko Hämäläisen raportille voi ennustaa korkeakoulumaailmassa aktiivista lukijakuntaa myös täydennyskoulutuslaitosten ulkopuolella. Siihen sisältyy nimittäin hyvin selkeä luku yliopistojen perusopetuksen arvioinnista. Kaikki yliopistomme joutunevat lähivuosina ulkopuolisen arvioinnin kohteeksi Jyväskylän ja Oulun yliopiston mallin mukaisesti.

Myös korkeakoulujen aikuiskoulutuksen ulkopuoliselle arviolle saattaisi nyt olla hyvä ajankohta. Korkeakoulujen joutuessa supistamaan toimintaansa on kaikki "uusi" ja "ytimen ulkopuolinen" vaarassa. Voisiko kansainvälinen arviointiryhmä vakuuttaa yliopistojemme rahanvartijoita täydennyskoulutuksen tarpeellisuudesta? 